\title{
Evaluation of textural properties of cooked beef batters
}

\author{
A Thesis Presented to the Faculty \\ Of California Polytechnic State University \\ San Luis Obispo, CA, USA
}
In Partial Fulfillment of the requirements for the Degree Master of Science in Agriculture, With Specialization in Animal Science

By

Lee Michelle Christensen

June 2012 
(C)2012

Lee Michelle Christensen

ALL RIGHTS RESERVED 


\section{COMMITTEE MEMBERSHIP}

TITLE: $\quad$ Evaluation of textural properties of cooked beef batters

AUTHOR: $\quad$ Lee Michelle Christensen

DATE SUBMITTED: June 2012

COMMITTEEE CHAIR: Dr. Robert J. Delmore Jr.

COMMITTEE MEMBER: Dr. Mark S. Edwards

COMMITTEE MEMBER: Dr. Rafael Jimenez-Flores 


\section{ABSTRACT \\ Evaluation of textural properties of cooked beef batters LEE MICHELLE CHRISTENSEN}

In the meat science industry the primary method used to determine the binding capabilities of a raw material is to reference the binding index created by Carpenter and Saffle (1964). This index is primarily based on the emulsification capabilities of meats and does not consider texture. As texture is one of the principal factors in determining acceptability of foods (Bourne, 1978), a testing method that captures textural attributes of raw materials is essential. This work was developed to capture raw material texture and cooking loss in a relatively quick manner.

Textural properties of cooked beef batters using two different salt levels $(0.00 \%$ and $1.80 \%$ ) and five different raw materials (finely textured beef (FTB), 90/10 trim, bull chuck meat, shank meat, and boneless trimmed finely textured beef (BTFT)) were evaluated. Combinations of raw material and salt $(\mathrm{N}=46)$ were analyzed using texture profile analysis. Texture profile analysis parameters: hardness, cohesiveness, springiness, gumminess, and chewiness were analyzed. Samples were also analyzed for $\mathrm{pH}$, fat, moisture, protein, and cook loss.

Texture profile analysis parameters: hardness, cohesiveness, and gumminess showed similar patterns when mean values were ranked highest to lowest. Within hardness texture parameter finely textured beef had a lower $(P<0.05)$ mean with a value of $25.46 \mathrm{~N}$. The raw material with a higher $(P<0.05)$ mean hardness value was shown to be beef shank meat with a mean of $84.47 \mathrm{~N}$. Gumminess texture parameter showed a very similar pattern with FTB having the lowest mean value (1710.25) and shank meat showing the highest mean value (6261.07). Cohesiveness texture parameter showed that BTFT had the lowest $(P<0.05)$ mean value $(0.63)$ 
and the highest mean value of (0.73). A consistent pattern of FTB as the lowest mean value and shank meat as the highest mean value was observed. 


\section{ACKNOWLEDGEMENTS}

Thank you to Dr. Robert Delmore for being a truly excellent mentor. His encouragement throughout the course of my master's studies will not be forgotten. Dr. Mark Edwards and Dr.

Rafael Jimenez, for opening their labs for my use, for their careful editing and for taking the time to guide me as a graduate student. Finally to my family and Mark Pierce, for their unending support. 


\section{TABLE OF CONTENTS}

\section{Page}

List of Tables $\quad$ viii

List of Figures $\quad$ iv

\section{Chapter 1: Literature Review}

1.1 Introduction 1

1.2 Protein Composition and Function 2

1.3 Protein Interactions 4

1.3.1 Protein-Water Interactions 4

1.3.2 Protein-Fat Interactions 5

1.3.3 Protein-Protein Interactions 8

$\begin{array}{ll}1.4 \text { Texture Analysis } & 10\end{array}$

1.5 Raw Materials 13

1.5.1 Ground Beef 13

1.5.2 Bull Meat 14

1.5.3 Shank Meat 14

1.5.4 Finely Textured Beef 15

1.5.5 Boneless Trimmings Finely Textured 16

$\begin{array}{ll}1.6 \text { Whey Protein } & 16\end{array}$

Chapter 2: Evaluation of textural properties of cooked beef batters

$\begin{array}{ll}2.1 \text { Introduction } & 19\end{array}$

2.2 Materials and Methods 20

2.2.1 Raw Materials 20

2.2.2 Sample Preparation $\quad 20$

2.2.3 Chemical Analysis and $\mathrm{pH} \quad 21$

2.2.4 Cook Loss 21

$\begin{array}{ll}\text { 2.2.5 Texture Analysis } & 21\end{array}$ 
2.2.6 Statistical Analysis $\quad 22$

2.3 Results $\quad 23$

2.3.1 Instrumental Texture Profile Analysis 23

$\begin{array}{ll}\text { 2.3.2 Chemical Analysis } & 24\end{array}$

2.3.3 Cook Loss 25

2.4 Discussion 25

2.4.1 Instrumental Texture Profile Analysis 25

$\begin{array}{ll}\text { 2.4.2 Cook Loss } & 26\end{array}$

$\begin{array}{ll}\text { 2.4.3 Chemical Analysis } & 27\end{array}$

$\begin{array}{ll}2.5 \text { Conclusion } & 27\end{array}$

2.6 Future Research $\quad 28$

$\begin{array}{ll}\text { Literature Cited } & 30\end{array}$ 


\section{LIST OF TABLES}

$\underline{\text { Table }}$

Page

Table 1: Formulations of meat batters prepared with different lean meat and salt levels

Table 2: Texture Profile Analysis texture parameters at salt level: 0.0\%

Table 3: Texture Profile Analysis texture parameters at salt level: $1.80 \%$

Table 4: Texture Profile Analysis texture parameters: combined salt levels

Table 5: Texture Profile Analysis texture parameters at salt level $0.00 \%$ and $1.80 \%$ : combined raw materials

Table 6: Cook Loss for all raw materials

Table 7: Chemical Analysis at Salt Level: 0.0\%

Table 8: Chemical Analysis at Salt Level: $1.80 \%$

Table 9: Chemical Analysis: combined salt levels 


\section{LIST OF FIGURES}

$\underline{\text { Figure }}$

Page

Figure 1: Illustration of a meat emulsion. Fat droplets are dispersed in an aqueous

medium that contains soluble proteins, segments of muscle fibers, and connective tissue fibers.

Figure 2: Texture profile analysis curves showing texture parameters 


\section{CHAPTER 1}

\section{Literature Review}

\subsection{Introduction}

Communition of meat is defined as the reduction in meat particle size by mechanical means (Aberle et al., 2001). Comminuted meat systems are commonly composed of lean meat, fat, water, salt and binders. The lean meat component of the comminuted meat system is the most important factor in producing high quality, desirable products; however, processors must also balance the cost of high quality lean meat proteins. Industry attempts have been made to index the quality of different raw materials. The most successful and commonly used is the binding index developed by Carpenter and Saffle (1964). Carpenter and Saffle (1964) investigated a wide range of beef and pork raw materials for their emulsion capacity - defined as the volume of oil that can be emulsified per gram of protein. Although regularly used in the industry, short-comings of the index have been considered. As an index that is based on the emulsification capacity of proteins - the aspects of protein matrix formation and textural properties of comminuted meat are unfortunately excluded from the indexing calculation. Further research around implementation of texture analyzing devices to measure the state of the protein matrix formed in comminuted meat products is needed. Objective tests have been successfully used in other foods to measure the deformation; these tests have been successfully correlated to responses of a subjective sensory panel (Friedman et al., 1963).

Manipulation of meat protein sources have been shown to affect the ability of different protein raw materials to bind to water, fat, and create a protein matrix. Factors such as protein concentration, $\mathrm{pH}$, temperature, and ionic strength can be modified to create a system that produces a product has a more stable protein matrix and is ultimately more desirable to 
consumers. Protein matrix stability is not only essential to the texture of the product but essential to the water and fat holding capacities of the comminuted meat system.

To supplement the binding capabilities of the protein matrix and increase the protein content to the lean meat portion, a variety of non-meat binders are used to improve emulsification capacity, immobilize water, stabilize the product during heating, and improve texture and organoleptic properties (Rakosky, 1970). Non-meat ingredients such as whey protein have been shown to improve the water and fat binding capabilities of the system as well as produce a more firm, desirable product. Water and fat interact with other ingredients to develop a desirable texture, mouth feel and assist with overall lubricity of food (Giese, 1996). All ingredients of a comminuted meat system are vitally important to the overall quality of the product and should be individually analyzed for their contributions before placing into the system.

\subsection{Protein Composition and Function}

The protein content in lean bovine meat is approximately 20\% (Aberle et al., 2001). Variations in protein content are based on age, muscle function, gender, breed and nutrition of the animal (Purslow, 2005). Lean meat proteins are categorized into three main types: myofibrillar, sarcoplasmic, and stromal proteins. Variations of protein types have been extensively studied and in comminuted meat systems, variation in ability for proteins to bind water, fat, and other proteins is of particular interest in an effort to optimize product quality.

Myofibrillar proteins make up the largest percentage of the total protein content ranging from 50-55\% (Morrissey et al., 1987). These proteins are present in the myofibril of the muscle fiber, which is primarily responsible for muscle contraction in the living animal. Components of myofibrillar proteins are actin, myosin, actinomyosin, tropomyosin, troponin, and other minor 
regulatory proteins (Pearson and Gillett, 1996). Myofibrillar proteins have been shown to be an excellent gelling agent in a comminuted meat system and are largely responsible for textural and structural characteristics (Foegeding et al., 1991), with myosin having the greatest binding capacity (MacFarlane et al., 1977). Disrupting membranes and sarcolema during communition is essential in freeing myofibrils into the meat system (Acton et al., 1983).

Sarcoplasmic proteins or water-soluble proteins consist of proteins found in the sarcoplasm or in the fluid surrounding the myofibril. Sarcoplasmic proteins comprise $30-34 \%$ of the total protein content (Tornberg, 2005). Sarcoplasmic proteins are considered water soluble due to their ability to be extracted with water or low ionic strength $(0.6 \mathrm{M})$ salt solutions (Pearson and Gillett, 1996). Proteins found in the sarcoplasm are myoglobin, albumins, enzymes and other globular proteins. These sarcoplasmic proteins are largely responsible for meat color (Mancini and Hunt, 2005) but have also been found to have a very limited role in protein binding in a processed meat system (MacFarlane et al., 1977). Although sarcoplasmic proteins play a limited role in the binding in a processed meat system, Farouk et al. (2002) showed they contribute slightly to the cohesiveness of a processed meat system.

Stromal proteins account for only $10-15 \%$ percent of the total protein content in meat proteins (Morrissey et al., 1987). Stromal proteins can be broken down into three main categories: collagen, elastin, and reticulin; commonly referred to as connective tissue.

Connective tissues in meat are known to be thermally stable and have a very low solubility (Purslow, 2005). The contribution of stromal proteins to emulsification of fats and water holding capacity in sausage is very low but can be slightly improved by the addition of salt (Pearson and Gillett, 1996). 


\subsection{Protein Interactions}

The term protein binding has been defined as 'binding together of pieces of meat to produce a unit system where adhesion of pieces of meat to each other is initiated by the mechanical formation of protein exudate, followed by protein gelation during thermal processing' (MacFarlane et al., 1977). In particular, the proteins of interest in meat gelation are myofibrillar or salt-soluble proteins, these proteins have the ability stabilize fat and water and are therefore of great interest in protein binding (Siegel et al., 1979).

\subsubsection{Protein-Water Interactions}

Comminuted meat systems are commonly comprised of lean meat, fat, water, and salt. Primary protein interactions of interest in this system are protein-water interactions, proteinprotein interactions, and protein-fat interactions. Generally, protein-water interactions are measured in terms of the water holding capacity of the meat or protein. Water holding capacity (WHC) can be explained as the water retained during cooking (Offer and Knight, 1988). Mechanisms of water holding capacity are related to the ability of proteins, specifically myofibrillar, to bind and entrap water (Huff-Lonergan and Lonergan, 2005). Water held in the meat system is found in the spaces between the myosin and actin filaments in post-mortem muscle (Offer and Knight, 1988). A small proportion of water is also held by electrostatic attraction between proteins (Hamm, 1986). The ability for water to remain bound to proteins can have a significant effect on the palatability and yield of the product.

One of the primary reasons salt $(\mathrm{NaCl})$ is added to meat products is to increase the ability of salt-soluble proteins to bind water and fat. The amount of salt added to meat products can dramatically affect water binding ability of proteins. Levels of salt added to meat can range from 0.5 to $5.0 \% \mathrm{NaCl}(0.1$ to $0.9 \mathrm{M})$ (Offer et al., 1989), but are limited by impacts on the palatability 
of the product. Optimal levels of salt in a comminuted meat system range from $2.0 \%$ to $3.0 \%$ $(0.47-0.60 \mathrm{M})$ (Ishioroshi et al., 1979). Variations of salt needed in a product are based on the desired extraction of protein (Gillett et al., 1977) as well as the protein: fat ratio (Ruusunen and Puolanne, 2005). Salt plays an essential role in binding and trapping water to salt soluble, myofibrillar proteins (Huff-Lonergan and Lonergan, 2005). The addition of salt to the meat system lowers the isoelectric point and creates a net negative charge on the protein. Repulsion of the negative charges results in a conformational change opening up the protein, allowing for more water binding to the protein (Hamm, 1960). Negatively charged chlorine ions bind to positive charges of the protein molecule (Schut, 1976). Increasing the negative charges on the proteins causes the myofibril to swell and more water is able to interact with the protein (Puolanne et al., 2001). In cooked meat products, adding salt increases the WHC of raw batter which results in lower cooking losses and a more desirable product when cooked (Barbut and Findlay, 1989).

\subsubsection{Protein-Fat Interactions}

Salt $(\mathrm{NaCl})$ also plays an essential role in protein-fat interactions in a comminuted meat system. Salt assists in emulsifying fat particles by conformationally opening up the proteins and the proteins coating the fat globules, minimizing the protein separation forces, and stabilize the product during cooking (Barbut and Findlay, 1989). Protein-fat interactions in comminuted meat systems are often associated with product desirability. There are two primary explanations to fat

stabilization in comminuted meat products: the emulsions theory and the gelation theory (Gordon and Barbut, 1992).

Emulsions are defined as a heterogenous mixture of two immiscible liquids, one of which is dispersed in the form of small droplets or globules in the other liquid. The liquid that forms 
the small droplets is called the dispersed-phase, whereas the liquid in which the droplets are dispersed is call the continuous phase. Examples of true emulsions are mayonnaise and homogenized milk. Oil and water emulsions consist of the liquids dispersed as small spherical droplets measuring between 0.1 and $100 \mu \mathrm{m}$. Proteins present in a meat system act as excellent emulsifiers due to their amphipathic nature (McClements, 2005). The amphipathic nature of proteins comes from different amino acids that are both hydrophobic (e.g., alanine, valine) and hydrophilic (e.g., arginine, aspartic acid) in nature (Petsko and Ringe, 2004). As proteins unfold hydrophobic portions of the protein will orient themselves toward the lipid phase and hydrophilic portions will orient themselves toward the continuous phase.

As discussed, myofibrillar proteins are of particular interest in meat systems. Specifically, myosin and actin are of key importance in emulsions (MacFarlane et al., 1977). The emulsion theory is based on formation of the interfacial protein film. Myofibrillar proteins can be absorbed on the surface of fat globules, creating an interfacial protein film (Gordon and Barbut, 1992). The amphiphilic nature of myofibrillar proteins prevents fat from coalescing (Barbut, 1995). Jones (1984) suggested that myosin formed a surface monolayer at the lipid-water interface. Shown by Zorba (2005), myofibrillar proteins maintain an adequate emulsion with up to $95 \%$ percent (by weight) added oil in a raw myofibril batter but only up to $70 \%$ added oil (by weight) when myofibrils undergo thermal treatment. The capacity of the emulsion is of importance in the meat industry as it is a part of bind value calculations. The emulsion capacity is a factor that reflects the solubility and the emulsion capacity of various meat components. Commercially, the emulsion capacity of a raw material is used to calculate a least cost formulation (Carpenter and Saffle, 1964). The least cost formulation software contains information on average performance attributes of raw materials such as water-binding capacity, 
color, and fat content. Least cost formulations are used to maintain low costs without increasing emulsion processing errors (Labudde and Lanier, 1995) and decreasing the quality of product produced.

Early studies in comminuted meats and meat protein emulsions revealed flaws in the emulsion theory. Lee et al. (1981) found some fat globules can be present at $>20 \mu \mathrm{m}$ in diameter suggesting comminuted meat systems should also in some circumstances be explained by the gelation theory. The gelation theory is described by Lee et al. (1981) as continuous protein gel matrix. The protein gel matrix is different from an emulsion in the interfacial film is the result of protein absorption on the surface of globule which is surrounded by a continuous liquid phase (Barbut, 1995). Regardless of the mechanism by which the batter is stabilized, the amount and type of protein extracted affects batter stability (Smith, 1988). The structure created by the matrix has been described by researchers as a sponge-like matrix that consists of protein strands interconnected surrounding fat globules (Barbut, 1995).

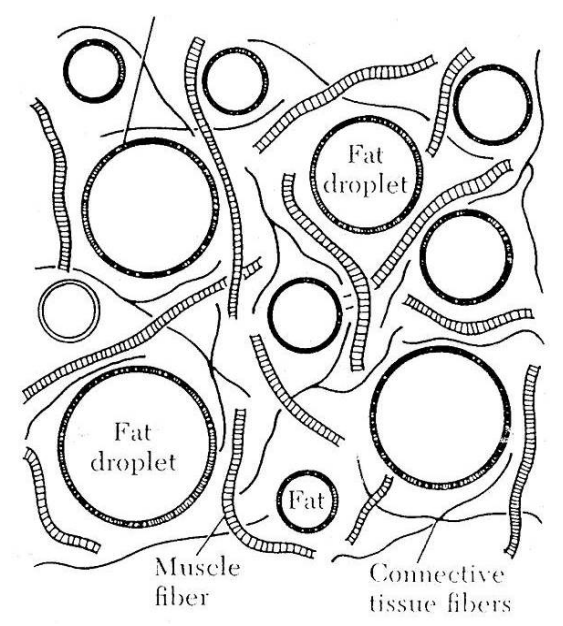

Figure 1: Illustration of a meat emulsion. Fat droplets are dispersed in an aqueous medium that contains soluble proteins, segments of muscle fibers, and connective tissue fibers. (Acton et al., 1983) 


\subsubsection{Protein-Protein Interactions}

The role of proteins in protein-protein interactions can be related to structural integrity of meat products through orderly heat-induced aggregation and are considered as being critical to processing of comminuted meat batters (Acton et al., 1983). Specifically, myofibrillar proteins are important in producing three dimensional gel matrices via protein-protein interactions. The gel matrix formed from protein-protein interactions has the ability to bind water and hold fat globules in emulsions (Xiong, 1997). After under-going thermal treatment, these protein matrixes are considered established and protein-protein interactions are stable.

The traditional molecular model of protein gelation consists of two steps; the initial unfolding of the proteins during thermal treatment revealing reactive sites for intermolecular binding, and the subsequent formation of protein-protein interactions that lead to the formation of a stable protein matrix (Totosaus et al., 2002). Proteins progressively pass from a native state to a denatured or unfolded transition and then to an aggregated network that eventually reaches a final rigid gel state (Ferry, 1948). For muscle proteins, thermal energy is the single most important driving force in protein transition from the native to the denatured state (Anglemier and Montgomery, 1976).

Many different factors can affect the ability of proteins to gel. These factors were categorized by Totosaus et al. (2002) as intrinsic and extrinsic factors or factors that are related to the protein and factors that are related to the environment surrounding the protein. Intrinsic factors include: electrostatic interactions, disulphide bonds and thiol-disulphide inter-change, molecular weight, amino acid composition, and hydrophobicity. Extrinsic factors or factors that are related to the environment surrounding the protein include: protein concentration, $\mathrm{pH}$, 
temperature, pressure and type of salt (Totosaus et al., 2002). Combinations of many of these factors attribute to the degree of protein gelation and the quality or strength of the protein matrix. Intrinsic factors or factors related to the protein or protein structure have been widely studied. As stated previously, one of the key intrinsic factors in protein gelation is electrostatic interactions. Net charge of the protein molecule is altered by attractive and repulsive forces. These forces effect the protein-protein interactions and the protein-water interactions (Phillips et al., 1994). Changes in ionic strength and $\mathrm{pH}$ are often associated with electrostatic changes of the protein. Another factor of interest is the disulphide bond and thiol-disulphide interchange. Disulfide bonds are created by a thiol- disulphide interchange and are considered to be very strong bonds. Keratin proteins in hair and feathers have a high disulfide content making the protein bonds very strong. The final factor highlighted is hydrophobicity. Because of the propensity for non-polar amino acids to position themselves in the interior of protein molecules in a solution, hydrophobic amino acids avoid contact with the aqueous solution (Rose et al., 1985). The combination of several different factors has a great effect on the stability and structure of the protein matrix.

Extrinsic factors of the meat system also have a great effect on the protein matrix and are often manipulated to increase the binding capacity of the meat. Protein concentration is one of these external factors. Gel strength and deformability are dependent on the protein concentration of the meat system (Hongspabhas and Barbut, 1997). Another key factor in the meat system is the $\mathrm{pH}$ of the system. The greater the net charge of the protein molecule, the greater the electrostatic repulsion between molecules, preventing the interactions required to form a gel matrix (Hermansson, 1979). The final extrinsic factor that can be manipulated is temperature. For a given rate of denaturation, the rate of aggregation slows as the attractive forces between the 
denatured protein chains are small, resulting in a fine network and translucent gel (Ferry, 1948). During cooling, increases in temperature will cause the peptides to aggregate and form a gel network (Pomeranz, 1991). Extrinsic factors of a meat system continue to be of interest to meat researchers and processors to due to their influence on the protein matrix formed in a meat system.

\subsection{Texture Analysis}

Texture has been defined by Bourne (2002) as the group of physical characteristics that arise from the structural elements of the food, are sensed by the feeling of touch, are related to the deformation, disintegration, and flow of the food under a force and are measured objectively by functions of mass, time and distances. Texture of a comminuted meat product is due to the functionality of the gelling properties of muscle protein components to produce desirable texture. Very similarly to Bourne's definition, the International Organization for Standardization has defined texture as "all the mechanical, geometrical and surface attributes of a product perceptible by means of mechanical, tactile and, where appropriate, visual and auditory receptors" (ISO, 1994). In a comminuted meat system, texture is used to evaluate not only the consumer desirability of the products but also the structural integrity of the protein matrix. The stability of the protein matrix is tested by "deformation, disintegration and flow" or the "mechanical, geometrical and surface attributes".

Instrumental, objective means for measuring the texture of food were first developed with the General Foods Texturometer (Friedman et al., 1963). The Texturometer was designed to imitate the action of a human jaw during the first bites of a food product. The instrument used a small, flat cylindrical disk which was forced down on the product, performing a two-cycle compression and is the technique of texture profile analysis (TPA) (Bourne, 2002). Compression 
texture parameters used in the texture profile analysis were outlined in an earlier study conducted by Bourne (1978) and remain as the texture parameters used in current research. These seven parameters were: hardness, chewiness, cohesiveness, fracturability, gumminess, springiness, and adhesiveness.

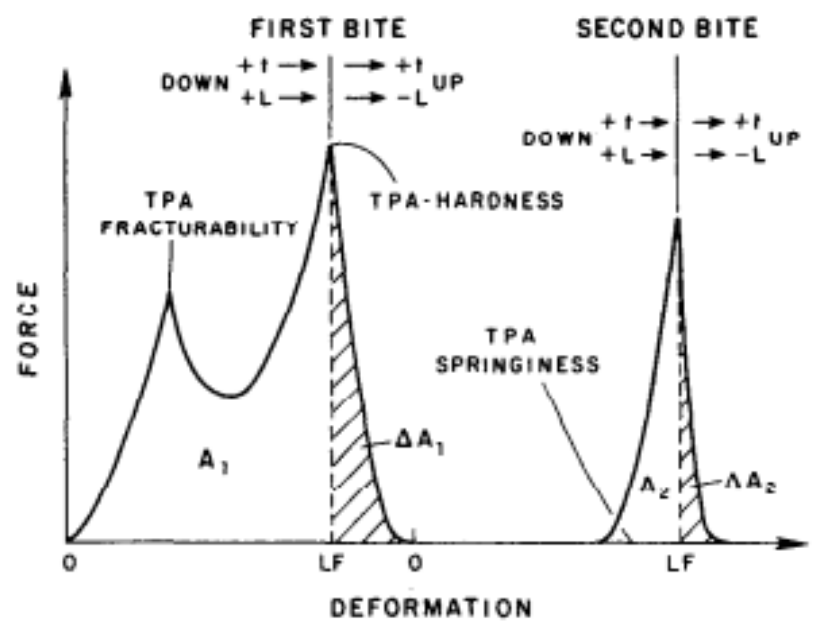

Figure 2: Texture profile analysis curves showing texture parameters (Figure 2 from Peleg, 1978) Although all parameters are discussed in the literature, the parameters most commonly discussed in reference to meat protein gelation are hardness, chewiness, cohesiveness, gumminess, and springiness. $\bullet$ Hardness describes a product which displays substantial resistance to deformation or the "first bite" that would be perceived by human sensory analysis (Bourne, 2002). Human subject sensory studies often refer to products on a scale of soft-firm-hard (Szczesniak, 1963). • Chewiness can be described as the textural property manifested by a low resistance to breakdown on mastication (Jowitt, 1974). Chewiness can be explained with a human sensory analysis on a scale of tender-chewy- tough. $\bullet$ Cohesiveness has been defined as the strength of the internal bonds making up the product (Szczesniak, 1963). Due to vagueness of Szczesniak's (1963) definition, further attempts to define the texture parameter were made. Most explanatory the definition by Munoz (1986) was "the amount of deformation undergone by 
the material before rupture when biting completely through sample using the molar".

- Gumminess, the energy required to disintegrate a semisolid food to a state ready for swallowing, and it is related to the primary parameters of hardness and cohesiveness (Szczesniak, 1963). On a subjective scale, cohesiveness can be described as mealy-pastygummy. - Springiness was determined as the force in which the sample returns to its original size after compression (Munoz, 1986) or the elasticity of the product. All attributes contribute to the overall acceptance and desirability of the food product. These attributes can also be an excellent measure for studying the strength of the protein matrix form during communition and heating.

Several other attempts to use mechanical devices to measure the texture and protein matrix strength of a product have been conducted. Most notably in reference to meat products, is the Warner Bratzler shear test (Caine et al., 2003). Caine and others (2003) compared the texture profile analysis test to Warner- Bratzler shear. Commonly used to measure tenderness of whole muscle cuts of meat, the Warner- Bratzler shear test seemed to be an obvious substitute. However, Caine and others (2003) concluded that texture profile analysis was a superior test in explaining the variations found using a human sensory panel. The Warner - Bratzler shear test was one dimensional and the shear force measurement most closely followed the texture profile analysis parameter - hardness.

Other attempts to measure the binding factors of a meat system have completely neglected the texture component of the binding ability of a protein and rather focused on the emulsion capacity of that particular protein (LaBudde and Lanier, 1995). This system is called the "bind value" system designed by Carpenter and Saffle (1964). Widely used in the meat industry, the bind value system primarily focuses on the emulsion capacity of a protein 
(Carpenter and Saffle, 1964). The system has been criticized for not addressing the aspect of texture in a meat system (LaBudde and Lanier, 1995).

\subsection{Raw Materials}

A variety of beef raw materials are used in the United States for ground beef and comminuted meat products. Selection of raw materials is often a balance between economics (price) and raw material functionality. Origin of the raw materials, physical properties, and extent of communition are all factors that can greatly influence finished product attributes. In an earlier study conducted by Carpenter and Saffle (1964), different meat-based proteins were indexed according to their 'bind value'. Protein sources such as bull meat and 90/10 trim had a very high bind value and therefore considered excellent protein sources to be used in a least cost formulation system (LaBudde and Lanier, 1995). The least cost formulation system is a mathematical system for reducing the cost of formulations while making the best use of raw materials. As new products continue to come on the market a need for a system in which processors can assess the ability for their raw materials to bind water, fat and create a strong protein matrix has become increasingly important.

\subsubsection{Ground Beef}

Ground beef in the United States is generally produced from beef trimmings. The United States Department of Agriculture (USDA) (1998) clearly defines ground beef as "chopped fresh or frozen been without: seasoning, addition of beef fat, additional water, phosphates, binders, or extenders and shall not contain more than $30 \%$ fat". The origin of the beef trimmings must be of skeletal muscle. Maximum percentage of fat allowed in ground beef must not exceed $30 \%$ (UDSA, 2011). Trimmings are reduced in particle size through a grinding apparatus, mixed and packaged (Berry and Leddy, 1984). 
Ground beef composition, which varies based on percentage fat, is approximately $75 \%$ water, 20\% protein and 5\% fat (Trout et al., 1992). The $\mathrm{pH}$ of ground beef is normally 5.4-5.6., common for post-rigor beef. Commonly, three main types of ground beef are sold in the U.S. ground round, ground chuck, and regular ground beef (Trout et al., 1992).

\subsubsection{Bull Meat}

Bull meat has a high water binding ability and is frequently used in sausages as a high protein meat source (Aberle et al., 2001). Bulls produce a leaner, more protein rich carcass in comparison to steers (Boggs et al., 1998). Bull meat also tends to have a higher pH (Graafhuis \& Devine, 1994), which results in a redder cooked product than products made from meats of normal $\mathrm{pH}$ (Mendenhall, 1989). Meat $\mathrm{pH}$ also has a profound effect on the water holding capacity of proteins. An increase in $\mathrm{pH}$ can cause the proteins unfold, allowing for more water binding to occur (Huff- Lonergan and Lonergan, 2005). Swan and Boles (2002) reported lower purge and higher cook yield from bull inside rounds with a higher $\mathrm{pH}$.

\subsubsection{Shank Meat}

Meat from the shank combination muscles in the beef carcass has been seen to have very high amount of connective tissue, low tenderness score, low flavor desirability score, and low overall palatability score (Jeremiah et al., 2003). Due to the high connective tissue content, shank meat is not used as a sole lean source in sausage products (Wiley et al., 1979). In fact, the inclusion of meat with high collagen content into ground beef can adversely affect ground beef quality (Cross et al., 1978). High collagen meats are also not recommended to be used in sausage manufacture, as quality defects are seen with meat blocks that contain $>15 \%$ collagen (Wiley et al., 1979). However, several studies found that desinewing improved the product 
quality (Gillett et al., 1976). When desinewing machines are used on shank meat, it has been shown to improve texture quality in low fat ground beef (Campbell et al., 1996).

\subsubsection{Finely Textured Beef}

In other attempts to recover lean raw material from collagenous material a process was developed using a low temperature rendering process to derive a beef product - Finely Textured Beef (FTB). The process in which the product is derived was patented at Cargill Meat Solutions (1995). Finely textured beef is derived from beef trimmings that could include: lean meat, fat, ligaments, and tendons. The process of deriving FTB begins with desinewing product by feeding it into a desinewing apparatus, which removes the heavy connective tissue, ligaments, and tendons. Mechanical desinewing removes approximately half of the connective tissue (Gillett et al., 1976) from the high quality lean protein.

The desinewed beef trimmings are fed into a head exchanger and heated to approximately $108^{\circ} \mathrm{F}$, to aid in melting fat from the lean portion. The liquefied desinewed beef is sent through a heat exchanger maintained at $115^{\circ} \mathrm{F}$ and is then sent to a particle reducer. The slurry is sent through a decanter which separates the heavy phase material, containing moisture and water soluble proteins and the light phase material, containing tallow. Liquids from the decanter go through a separator, and the heavy phase stream is combined with decanter solids.

Due to the very low thermal treatment in deriving finely texture beef, under USDA standards is considered high quality lean and can be labeled as meat (USDA, 1998). The product composition of the FTB product is typically $14 \%$ protein, $5 \%$ fat $\pm 2 \%$, and $78 \%$ moisture $\pm 3 \%$ (Hobbs, 2012). Protein composition of finely textured beef has been found to have a $46.47 \%$ higher concentration of insoluble proteins and collagen compared to beef chuck (He and Sebranek, 1996). 


\subsubsection{Boneless Trimmings Finely Textured}

Boneless trimmings finely textured (BTFT) are derived from an advanced meat recovery (AMR) process. Advanced meat recovery systems specifically designed equipment designed to separate edible meat from bone. Vertebral and non-vertebral bones from the fabrication process are processed through three inter-connected pieces of equipment that involves a controlled pressure process to separate the lean from bones. This technology was approved by the United States Department of Agriculture (1998) as a quality source of lean meat and as permitted, to be labeled as meat because the machines do not grind, crush, or pulverize the bones. Rather the high pressure system removes the lean from the bone, much like would be found from hand-boning the same bones. Resulting AMR systems produce distinct pieces of skeletal muscle tissue (USDA, 1998). Hajmeer et al.(2006) explored concerns about the presence central nervous system (CNS) tissue in the lean meat and found the AMR product almost identical to boned product and containing less $<0.1 \%$ CNS in all the samples tested.

Use of additional processing techniques such as AMR system can compromise the protein quality and therefore the protein binding abilities. Non- meat proteins can be added to enhance the texture of meat products (Lanier, 1991) and compensate for lower or reduced quality proteins. Addition of non-meat proteins may improve yield, textural properties and potentially reduce cost of the meat formulation (Hung and Smith, 1993). Whey proteins are one of the most common uses of non-meat proteins due to the ability to form a protein gel at a low concentration and in the presence of salt $(\mathrm{NaCl})$ (Hongsprabhas and Barbut, 1997).

\subsection{Whey Protein}

Whey is the liquid remaining after removal of casins from milk and contains small, globular whey proteins. Whey proteins are composed of 5 major components including: $\alpha$ - 
lactalbumin, $\beta$ - lactalbumin, lactoglobulin, bovine serum, and immunoglobulin (Swaisgood, 1996). Whey protein concentrates differ in composition, nutritional quality and function depending on the process of preparation. Whey protein products are categorized on the basis of their composition; mostly based on their protein content (Huffman, 1996). The composition of the whey products not only affects the price of whey products but also affects the functionality of whey products.

Stability, yield, texture, palatability and cost are the five major criteria for use of whey protein in meat products. The ability of whey proteins to form gels and provide a structural matrix for holding water and lipids is very useful (Hoogenkamp, 2001). In processed meats, whey protein has been shown to be an especially valuable binder or extender to improve cooking yield and textural properties of the meat products (Mittal and Usborne, 1985). Whey protein is commonly used in the meat industry to improve the texture and binding properties.

Eli-Magoli and others (1996) reported on the functionality of whey protein in a meat system. They reported that myofibril proteins started to shrink and coagulate around $60^{\circ} \mathrm{C}$; and as the cooking temperature increased, shrinkage and coagulation of the myofibrils proteins also increased. When whey proteins were added to the beef patties, shrinkage and coagulation of the myofibrils proteins were decreased by the presence of whey proteins. Whey proteins seemed to serve as a filler by occupying the intracellular and intercellular spaces. This protective action of whey proteins seemed to stabilized the protein matrix and retain water.

Whey proteins can also be used to improve emulsifying capacity and emulsion stability in comminuted meat products. Hung and Zayas (1992) reported all beef frankfurters containing $3.5 \%$ whey protein concentrate (WPC) had increased water holding capacity and decreased cook loss. When studied under an electron transmission microscope, frankfurters with 3.5\% WPC 
have a fine protein - fat matrix with less coalescence of fat droplets (Atughonu et al., 1998).

These results support the importance of binders like whey protein isolate in a comminuted meat product and their ability to aid in forming a strong protein - fat matrix. 


\section{CHAPTER 2}

\section{Evaluation of textural properties of cooked beef batters}

\subsection{Introduction}

Processors of beef raw materials are looking for methods to capture the binding capabilities of the raw materials used in formulations. To date, the primary analysis used in determining the binding capabilities of a raw material is to reference the binding index created by Carpenter and Saffle (1964). This index is primarily based on the emulsification capabilities of meats and does not consider texture. Processors today consider the bind value system to be out of date and limited in its ability to characterize the daily fluctuation seen in raw materials. Processors are also finding that as new raw materials enter the market (ex: FTB and LFTB); continuing research is not being conducted to establish bind values of these new raw materials. In response to industry needs, researchers are working to develop other repeatable, objective tests to provide a more rapid mechanism to determine binding and textural qualities of meat raw materials.

Texture is one of the principal factors in determining acceptability of foods (Bourne, 1978). The basic texture of a wide variety of foods is based on the gelling properties of proteins and polysaccharides. Texture profile analysis (TPA) is an objective test commonly used in other industries for texture assessment of foods. Texture profile analysis uses a double compression cycle to simulate the first and second bites, similar to a human subject. Texture parameters that

can be assessed using TPA are: hardness, cohesiveness, springiness, gumminess, and chewiness. Utilization of these texture parameters has been proven a useful method in determining textural properties of food. 
The objective of this work was to utilize texture profile analysis parameters to determine differences between cooked meat batters manufactured with different meat raw materials.

\subsection{Materials and Methods}

\subsubsection{Raw Materials}

Meats: finely textured beef (FTB), beef trim (BT), bull chuck meat (BCM), shank meat (SM) and boneless trimmed finely textured beef (BTFT) were obtained from a commercial beef plant in $22.7 \mathrm{~kg}$ vacuum packed Cryovac bags (Duncan, SC). All raw materials were selected from the same plant on the same fabrication day. Finely textured beef was received in frozen pellet form and tempered in a $5^{\circ} \mathrm{C}$ cooler until product reached $\geq 0^{\circ} \mathrm{C}$. Beef trim, bull chuck meat, shank meat, and boneless trim finely textured were received fresh and were stored at $5^{\circ} \mathrm{C}$. Beef trim, bull chuck meat, and shank meat were individually ground in a grinder (Butcher Boy, Model A42, Lascar MFG. Company, Los Angeles, CA) through $4.75 \mathrm{~mm}$ plate. All raw materials were held at $5^{\circ} \mathrm{C}$ overnight. Whey protein isolate (WPI) (Davisco Foods International, Eden Prairie, MN) contained $96.2 \%$ protein (dry weight basis), 1.54\% sulfated ash, and 5\% moisture.

\subsubsection{Sample Preparation}

A total of ten formulations were prepared (Table 1) by randomly selecting smaller increments from the larger $22.67 \mathrm{~kg}$ batch of raw material. Meat, whey, ice and salt (formulation dependent) were combined in a tabletop bowl chopper (Robocoupe RSI 2Y-1, Jackson, MS). Ice was included in formulations to keep batter temperatures $\leq 15^{\circ} \mathrm{C}$. Raw materials were chopped for $45 \mathrm{sec}$ at $3450 \mathrm{rpm}$. Final recorded batter temperatures for all treatments did not exceed $15^{\circ} \mathrm{C}$. Each batter formulation was then manually stuffed into $50 \mathrm{ml}$ polypropylene tubes (Corning 4558, Corning Incorporated, Corning, NY) and capped $(n=46)$. Samples were 
centrifuged (Eppendorf 5804 R, West Bury, NY) at 1500 RPM for 30s to remove any large remaining air bubbles in tubes. Tubes containing batter were immersed in a water-bath for 45 $\min$ at $55^{\circ} \mathrm{C}$. After $45 \mathrm{~min}$ at $55^{\circ} \mathrm{C}$, water-bath temperatures were increased to $75^{\circ} \mathrm{C}$ for an additional hour.

\subsubsection{Chemical analysis and $\mathrm{pH}$}

Raw batter samples were collected in triplicate for moisture, fat and protein analysis (He and Sebranek, 1996). Moisture was determined by an outside laboratory using forced-air (AOAC, 2005). Fat analysis was completed using Soxtec extraction method (AOAC, 2005) and protein using nitrogen determiner by combustion method (AOAC, 2005). The $\mathrm{pH}$ of batters was measured (Accumet AB15, Fischer Scientific, Waltham, MA). Samples were collected in triplicate and averaged.

\subsubsection{Cook loss}

Fluid separated during the cooking process was measured after placing samples in an ice water bath at $0.0^{\circ} \mathrm{C}$ for 5 minutes (Youssef and Barbut, 2009). Cooked sample was removed from polypropylene tube and weighed. The cook loss value was expressed as initial raw batter weight - final cooked batter weight divided by initial raw batter weight $(\mathrm{CL}=(\mathrm{F}-\mathrm{I}) / \mathrm{I})($ percent loss). Samples removed from tubes were stored in a $5^{\circ} \mathrm{C}$ cooler overnight on covered trays.

\subsubsection{Texture Analysis}

After overnight storage $\left(5^{\circ} \mathrm{C}\right)$, samples were cut into standardized cores. Each core was cut to measure $28 \mathrm{~mm}$ in diameter and $10 \mathrm{~mm}$ in height (Youssef and Barbut, 2009). Cores were cut perpendicular to the horizontal axis of the samples using a knife. Cores were analyzed using texture profile analysis as described by Bourne (1978). Samples were compressed to $50 \%$ of their original height by a Texture Analyzer (Sable Micro Systems Model TA. XT2, Texture 
Technologies Corp., Scarsdale, NT). Settings for the Texture Analyzer were: test speed: 1.2 $\mathrm{mm} / \mathrm{s}$, rupture test distance: $4 \mathrm{~mm}$, distance: $5 \mathrm{~mm}(50 \%)$, force: $100 \mathrm{~g}$, time: 5 seconds, load cell: $25 \mathrm{~kg}$, trigger: auto $-5 \mathrm{~g}$.

Texture parameters hardness, springiness, cohesiveness, gumminess, and chewiness were obtained from Texture Analyzer or calculated. Hardness (N) was defined as the maximum load applied to the samples during first compression. Springiness $(\mathrm{mm})$ was calculated to be ratio of the duration of contact with the sample during the second compression to that during the first compression. Cohesiveness was the ratio of the area under the curve of the second compression to the area under the curve of the first compression. Chewiness was calculated as the product of hardness $\mathrm{x}$ cohesiveness $\mathrm{x}$ springiness (Formula1: $\mathrm{c}=\mathrm{h} * \mathrm{co}^{*} \mathrm{~s}$ ) (Meullenet et al., 1998).

\subsubsection{Statistical Analysis}

The experiment was designed as a $5 \times 2$ factorial, the five different raw materials (FTB, 90/10 trim, bull meat, shank meat and BTFT) by the two different salt levels (0.00\% and $1.80 \%)$. An analysis of variance was conducted using PROC MIXED (SAS Inst. Inc. Cary, NC) to test mean levels of different raw materials, salt levels, and salt x raw material interaction. Analysis of variance was carried out for each texture parameter, chemical analysis parameter, and cook loss. Each sample was the experimental unit. Tukey's multiple comparison analysis was performed to separate the means $(P<0.05)$. Confidence limits of $95 \%$ were shown to define the likely range of the true value for each textural parameter. 


\subsection{Results}

\subsubsection{Instrumental Texture Profile Analysis}

There were differences $(P<0.01)$ between raw materials for instrumental hardness, cohesiveness, springiness, chewiness, and gumminess (Table 2). Means of hardness, cohesiveness, and gumminess for each raw material were different $(P<0.01)$ and followed a similar pattern when ranking sample means from highest mean value to lowest mean value. Samples with $1.8 \%$ salt had higher $(P<0.05)$ hardness, springiness, chewiness and gumminess values than $0.0 \%$ salt level (Table 5). Within the texture parameter - springiness, mean value rankings were the inverse of those seen in other texture parameters, with boneless trimmed finely textured beef and finely textured beef having a significantly higher springiness mean value than other raw materials.

FTB samples had the lowest $(P<0.01)$ score for hardness, gumminess, and chewiness across all raw materials (Table 4). At salt level 0.0\%, FTB had lower $(P<0.01)$ scores than other raw materials in all texture parameters except springiness (Table 2). Similarly, FTB scored significantly lower than all other raw materials at salt level 1.8\% (Table 3). For instrumental parameter springiness, FTB was seen to have a significantly higher mean values than 90/10 trim, bull meat, and shank meat. With salt added, the hardness mean for FTB was found to be between 22.9- $37.2 \mathrm{~N}$ with $95 \%$ confidence.

No textural differences $(P>0.05)$ were found between shank meat and bull meat (Table 4). Samples of shank meat and bull meat displayed similar $(P>0.05)$ high values hardness, cohesiveness and gumminess (Table 4). Inversely, for instrumental springiness, both raw materials displayed lower scores than other raw materials. Between salt levels ( $0.0 \%$ and $1.8 \%)$ 
a difference of $20.8 \mathrm{~N}$ was shown (Table 5). Hardness values for shank meat with salt added at $1.8 \%$ were found to be between $89.9-99.7$ with a $95 \%$ confidence interval.

BTFT was lower $(P<0.05)$ than shank meat, bull meat, and $90 / 10$ in instrumental parameters hardness, cohesiveness, gumminess, and chewiness (Table 4). Differences between $0.0 \%$ salt levels and $1.8 \%$ salt levels were significant in all texture parameters (Table 5). True mean hardness values for BTFT was found to be in the range of 56.9 - 63.8 , with $95 \%$ confidence. Lower mean values for BTFT could be attributed to the higher collagen content. With additional processing involved in manufacturing BTFT, it is likely that proteins are denatured in making the product. High pressures $(\geq 200 \mathrm{MPa})$ used in AMR systems have been shown to denature proteins and alter their functionality in comminuted meat systems (Cheftel and Culioli, 1997)

\subsubsection{Chemical Analysis}

The $\mathrm{pH}$ range of raw materials was 5.58 to 6.13. All raw materials were different $(P<$ 0.05) from each other in both the $0.0 \%$ salt level and the $1.8 \%$ salt level (Table $6 \& 7$ ). Samples with $1.8 \%$ salt had significantly higher $(P<0.01) \mathrm{pH}$ values than $0.0 \%$ salt level.

Fat levels of the raw materials were all different $(P<0.01)$. The highest mean fat value was boneless trimmed finely texture beef (BTFT) at $21.70 \%$ and was higher $(P<0.01)$ than all other raw materials (Table 3). The lowest mean fat value was beef chuck trim at 1.86 which was significantly lower than all other beef raw materials.

Mean moisture percentages for all beef raw materials were different $(P<0.01)$. BTFT had the lowest mean moisture percentage $(58.28 \%)$ and is lower than other raw materials $(P<$ 0.01). The highest mean moisture percentage was finely textured beef (FTB) which was lower $(P<0.05)$ than other beef raw materials. 
Protein percentages found in the beef raw materials were all significantly different when compared to each other $(P<0.01)$. The range of value for mean protein percentages was between $16.52 \%-20.52 \%$. The highest mean value in this range was found in bull chuck trim, which was found to be higher $(P<0.05)$ than all other raw materials. Lowest mean value was BTFT and was significantly lower than other raw materials.

\subsubsection{Cook Loss}

Mean cook loss values were different $(P<0.01)$ across all raw materials excluding salt as a factor. Finely textured beef (FTB) had the highest mean value of percent cook loss with a value of $27.51 \%$. Lowest mean percentage weight loss was $90 / 10$ trim, with a mean value of 20.24\%. Mean cook loss for the two different salt levels ( $0.00 \%$ and $1.80 \%)$ were significantly different with the salt level of $1.8 \%$ having a lower mean cook loss value than the $0.00 \%$ salt level.

\subsection{Discussion}

\subsubsection{Instrumental Texture Profile Analysis}

Instrumental texture parameters hardness, cohesiveness and gumminess followed a similar pattern of raw material mean values ranked from highest to lowest. Significant differences $(P<0.05)$ were found between raw materials within hardness, cohesiveness and gumminess texture parameters. Similar patterns were seen in a study by Caine et al. (2003) indicating that the texture profile parameters for determining tenderness in a steak were hardness and cohesiveness.

When evaluating hardness, cohesiveness, and gumminess texture parameters, finely textured beef $($ FTB $)$ had a significantly lower $(P<0.05)$ mean values than other raw materials. Lower textural values are consistent with the findings of He and Sebranek (1996) with a similar low thermal treatment beef product. Finely textured beef mean value for hardness was $25.46 \mathrm{~N}$ 
compared to boneless trimmed finely textured beef (BTFT) $60.24 \mathrm{~N}$, which was the second lowest hardness mean value. Because BTFT also and AMR (advanced meat recovery) product and had a higher percentage of fat, lower mean hardness values were expected.

With a high prevalence of stromal proteins, shank meat is considered a tough and less palatable cut of meat (Jeremiah et al., 2003). A high prevalence of stromal proteins, insoluble protein could explain the high hardness value. Neely et al. (1999) showed that when highly collagenous meat samples were cooked in the presence of water and heat, palatability of the samples was significantly higher than those cooked with a dry heat method.

Bull chuck meat had the second highest mean value in terms of hardness and gumminess and was the highest mean value with texture parameter cohesiveness. Due to the high protein content (Boggs et al., 1998) and high pH values (Graafhuis and Devine, 1994), the binding capacity and resulting texture can explain the higher values seen in beef bull meat.

\subsubsection{Cook Loss}

FTB had the highest mean cook loss percentage with a mean percentage of $25.54 \%$. High cook loss values are consistent with the findings of He and Sebranek (1996) compared to beef chuck trim. Conversely, the lowest percentage cook loss was seen to be 90/10 beef trim which was according to the study completed by Carpenter and Saffle (1964) one of the highest bind values, relating to the ability for raw materials to hold an emulsion. Mean percentages for both beef bull meat and beef shank meat were fairly consistent with the Saffle (1964) bind values. High cook loss values for FTB could be explained by a $22.36 \%$ higher collagen content (He and Sebranek, 1996) than beef chuck. Thermal treatment in the processing of Finely textured beef $\left(115^{\circ} \mathrm{F}\right)$ can also result in lower functionality of myofibrillar proteins due to protein 
denaturation. Higher collagen content in FTB and a lowered functionality of myofibrillar proteins from elevated processing temperatures, higher cook loss values can be explained.

\subsubsection{Chemical Analysis}

Chemical analysis of the raw materials was consistent with other studies on beef raw materials. Bull chuck meat and shank meat were significantly leaner than the other beef raw materials. Although BTFT had a significantly higher mean fat percentage, the value was very similar to that of the supplier fact sheet and product specifications provided. Comminuted meat formulations with high fat percentages will produce products with softer textural values (Mallika and Prabhakar, 2011). A lower fat percentage in comminuted meat formulations often increases the total protein percentage and can make products more rubbery and dry.

\subsection{Conclusion}

Texture profile analysis parameters: hardness, cohesiveness and gumminess were shown to be most useful in determining the textural properties of cooked beef batters. These parameters demonstrated a pattern from highest textural value to lowest textural value: shank meat, bull chuck meat, 90/10 trim, BTFT, and FTB. Ranking these key texture parameters are important to processors when selecting raw materials. Knowing the textural properties of raw materials will allow processors to choose raw materials that not only can offer a cost savings but will also maintain product quality. Less expensive raw materials with lower key textural values can still be used, but should be used at levels in which textural properties are not jeopardized. Different raw material blends can be tested and key texture and binding information can be captured aiding the processor in determining final product formulation.

Cook loss percentages were highest in finely textured beef (FTB), followed by boneless trimmed finely textured beef, bull chuck meat, shank meat and 90/10 trim. Lower cook losses 
were seen at $1.80 \%$ salt compared to $0.00 \%$ salt. Higher salt levels significantly reduced cook loss and increased key texture parameters. In a comminuted meat system, it is vital that products are able to retain adequate water. If products such as FTB with a high cook loss are used, processors should carefully consider usage rates as the quality of their products could be greatly altered if incorporated at rates that are too high. As seen in this study, salt had a significant effect on all raw materials and can an excellent processing aid for processors to minimize cook losses in comminuted meat products.

Application of the above technique can be useful in the meat industry to characterize binding properties of raw materials used in comminuted meats. Processors can take samples from production and semi-rapidly determine the binding and textural properties of the raw material tested. The method used can be utilized in a plant setting with a small workspace and little capital investment. For processors, texture parameters: hardness, cohesiveness and gumminess showed similar patterns and are recommended to capture textural similarities and differences in raw materials. Cook loss percentages show the ability for meat proteins to bind water and fat, and should continue to be used as a means of fully characterizing raw materials. Information from the test can help small processors demonstrate differences and attempt to reduce variation in raw materials received from suppliers. The ability to compare raw materials on a regular basis will allow processors to produce a more consistent product to consumers.

\subsection{Further Research}

Future research in this area should be conducted to characterize additional raw materials and /or combinations of raw materials. FTB and ground beef combinations should be tested to establish textural and binding thresholds for meat processors. Characterizing additional raw materials could ensure that the testing method in this study could be used across different species 
and raw materials. Pork and poultry raw materials should be used to capture differences in binding and textural properties. It is recommended that 90/10 trim and FTB continue to be used as high and low binding anchors for future research. Recommended methodology should focus on salt or no salt rather than comparing both salt levels. This modification would allow a greater number of products could be tested. Future research will continue to prove efficacy of the described method and thus providing processors with confidence in the system's use commercially. 


\section{Literature Cited}

Aberle, E. D., J. C. Forrest, D. E., Gerrand, and E. W. Mills. 2001. Principles of Meat Science. $4^{\text {th }}$ ed. Kendall Hunt Publishing Company, Dubuque, IA.

Acton, J. C., G. R. Ziegler, and D. L. Burge. 1983. Functionality of muscle constituents in the processing of comminuted meat products. Crit Rev Food Sci Nutr. 18: 99-121.

Anglemier, A. F. and M.W. Montgomery. 1976. Amino acids, peptides, and proteins. Food Chem. 205.

AOAC. 2005. Official methods of Analysis, $18^{\text {th }}$ ed. Association of Official Analytical Chemists, Washington, DC.

Atughonu, A.G., J. F. Zayas, T.J. Herals, and L.H. Harbers. 1998. Thermo-rheology, quality characteristics, and microstructure of frankfurters prepared with selected plant and milk additives. J. Food Qual. 21: 223-238.

Bailey, A. J. 1972. The basis of meat texture. J. Sci. Food Agric. 23: 995- 1007.

Barbut, S. 1995. Importance of fat emulsification and protein matrix characteristics in meat batter stability. J. Muscle Foods. 6:61-72.

Barbut, S. and C. J. Findlay. 1989. Sodium reduction in poultry products: A review. Poultry Bio. 2: 61-93.

Berry, B.W. and K. F. Leddy. 1984. Effects of fat level and cooking method on sensory and textural properties of ground beef patties. J. Food Sci. 49:870-875.

Boggs, D. L., R. A. Merkel, and M. E. Doumit. 1998. Livestock and carcasses, an integrated approach to evaluation, grading and selection. Kendall/Hunt Publishing. Dubuque, IA. 
Bourne, M. C. 1978. Texture Profile Analysis. Food Technol. 32: 62- 66,72.

Bourne, M. C. 2002. Food Texture and Viscosity: Concept and Measurement. $2^{\text {nd }}$ Ed. Academic Press. Waltham, MA.

Caine, W. R., J. L. Aalhus, D. R. Best, M. E. R. Dugan, and L. E. Jeremiah. 2003. Relationship of texture profile analysis and Warner-Bratzler shear force with sensory characteristics of beef rib steaks. Meat Sci. 64: 333-339.

Campbell, R. E., M. C. Hunt, D. H. Kropf, and C. L. Kastner. 1996. Low fat ground beef from desinewed shanks with reincorporation of processed sinew. J. Food Sci. 41:1285-1288.

Cargill Meat Solutions, D. L. Schaefer, R. M. James, and M. E. Rempe. 1995. U. S. Patent No. 5725897. Washington, DC. U. S. Patent and Trademark Office.

Carpenter, J. A. and R. L. Saffle. 1964. A simple method of Esimating the Emulsifying Capacity of Various Sausage Meats. J. Food Sci. 29:774-781.

Cheftel, J.C., and J. Culioli. 1997. Effects of High Pressure on Meat: A Review. Meat Sci. 46: 211-236.

Creighton, T. E. 1988. Disulphide bonds and protein stability. BioEssays. 8: 57-63.

Cross, H. R., B. W. Berry, J. E. Nicols, R. S. Elder, and J. A. Quick. 1978. Effect of disinewing versus grinding on textural properties of beef. J. Food Sci. 43: 1507.

El-Magoli, S. B., S. Laroia, and P. M. T. Hansen. 1996. Flavor and texture characteristics of low fat ground beef formulated with whey protein concentrate. Meat Sci. 42: 179-193. 
Farouk, M. M., .J. Wieliczko, R. Lim, S. Turnwald, G.A. MacDonald. 2002. Cooked sausage batter cohesiveness as affected by sarcoplasmic proteins. Meat Sci. 61: 85-90.

Ferry, J. D.1948. Protein Gels. Adv Protein Chem. 4: 1-78.

Foegeding, E. A., J. B. Clark, and Y.L. Xiong. 1991. Interactions of Food Proteins. Chapter 18 pp 257- 267.

Friedman, H. H., J. E. Whitney, and A. S. Szczesniak. 1963. The texturometer- a new instrument for objective texture measurement. J. Food Sci. 28: 390- 396.

Giese, J. 1996. Fats, oils and fat replacers. Food Technol. 50:78-83.

Gillett, T. A., K. Tantikarnjathep, and S. J. Andrews. 1976. Mechanically desinewed meat: its yield composition and effect on palatability of cooked salami. J. Food Sci. 41: 766-769.

Gillett T A, D.E. Meiberg, C.L. Brown, S. Simon.1977. Parameters affecting meat protein extraction and interpretation of model system data for meat emulsion formation. J. Food Sci 42: 1606-1610.

Gordon, A. and S. Barbut. 1992. Effect of chloride salts on protein extraction and interfacial protein film formation in meat batters. J. Sci. Food Agri. 58: 227-238.

Graafhuis, A. E., and C. E. Devine. 1994. Incidence of high pH beef and lamb II: results of an ultimate pH survey of beef and sheep plants in New Zealand. Pages 133-14 in Proc. 28th Meat Ind Research Conf. Auckland, New Zealand.

Hajmeer, M.N., D.O. Cliver, and J. L. Marsden. 2006. Central nervous system tissue detection in meat from advanced meat recovery systems. Meat Sci. 72: 656- 659.

Hamm, R. 1960. Biochemistry of meat hydration. Adv. Food Res. 10: 355. 
Hamm, R. 1986. Functional properties of the myofibrillar system and their measurements. Pp 135-199. Muscle as food. In P. J. Bechtel (Ed.), Academic Press, Inc, New York, NY.

He, Y. and J. G. Sebranek. 1996. Frankfurter with Lean Finely Textured Tissue as Affected by Ingredients. J. Food Sci. 61: 1275- 1279.

Hermansson, A.M. 1979. In "Functionality and Protein Structure" (Ed. A. Por-El) Am.Chem.Soc., Washington DC. Series 92; 81.

Hobbs, M. 2012. Personal Communication. January 16, 2012.

Hongsprabhas, P. and S. Barbut. 1997. Protein and salt effects on $\mathrm{Ca}^{2+}$ induced cold gelation of whey protein isolate. J. Food Sci. 62: 382-385.

Hoogenkamp, H.W. 2001. Soy protein \& meat formulations, In Lifestyle Marketing Dynamics Coupled With Modern Processing Techniques and Old Time Favorites, published by Protein Technologies International - A DuPont Business P.O. Box 88940, St Louis, MO 63188.

Huff-Lonergan, E. and S. M. Lonergan. 2005. Mechanisms of water holding capacity of meat the role of post mortem biochemical and structural changes. Meat Sci. 71: 194-204.

Huffman, L.M. 1996. Processing whey protein for use as a food ingredient. Food Technol. 50(2): $49-52$.

Hung, T. Y. and D. M. Smith. 1993. Dynamic rheological properties and microstructure of partially insolubilized whey protein concentrate and chicken breast salt-soluble protein gels. J. Agric. Food. Chem. 41:1372-1378. 
Hung, S. C. and J. F. Zayas. 1992. Functionality of milk proteins and corn germ protein flour in comminuted meat products. J. Food Qual. 15: 139.

Ishioroshi, M., K. Samejima, and T. Yasui. 1979. Heat induced gelation of myosin: factors of pH and salt concentrations. J. Food Sci. 44: 1280 -1284.

ISO 11036. 1994. Sensory analysis. Methodology. Texture profile.

Jeremiah, L. E., L. L. Gibson, J. L. Aahus, and M. E. R. Dugan. Assessment of palatability attributes of the major beef muscles. 2003. Meat Sci 65: 949-958.

Jowitt, R. 1974. The terminology of food texture. J. Texture Stud. 5: 351-358.

Jones, K. W. 1984. Protein lipid interactions in processed meats. In Proceedings of the 37th annual reciprocal meat conference (pp. 52-57). Chicago, IL.

LaBudde, R. A. and T. C. Lanier. 1995. Protein functionality and development of bind values. $48^{\text {th }}$ Annual Reciprocal Meat Conference. 59- 68.

Lanier, T. C., 1991. Interactions of muscle and non-muscle protein affecting heat-set gel rheology. Interactions of Food Proteins. American Chemical Society, Washington, DC.

Lee, C. M., R. J. Carroll, and A. Abdollahi. 1981. A microscopical study of the stricter of meat emulsions and its relationship to thermal stability. J. Food Sci. 46: 1789 - 1804.

MacFarlane, J. J., G. R. Schmidt, and R. H. Turner. 1977. Binding of meat pieces: A comparison of myosin, actomyosin, and sarcoplasmic proteins as binding agents. J. Food Sci. 42: 1603-1605. 
Mallika, E. N. and K. Prabhakar. 2011. Physico- chemical properties of low fat pork sausages. J. Agri. \& Environ. Sci. 10: 160-162.

Mancini, R. A. and M. C. Hunt. 2005. Current research in meat color. Meat Sci. 71:100-121.

McClements, D. J. 2005. Food Emulsions - Principles, practices and techniques. $2^{\text {nd }}$ Ed. CRC Press. Boca Raton, FL.

Mendenhall, V. T. 1989. Effect of $\mathrm{pH}$ and total pigment concentration on internal color of cooked ground beef patties. J. Food Sci. 54: 1-3.

Meullenet, J. F., B. G. Lyon, J. A. Carpenter, and C. E. Lyon. 1998. Relationship between sensory and instrumental texture profile attributes. J. Sensory Stud. 13:77-93.

Mittal, G. S. and W. R Usborne. 1985. Meat emulsion extenders. Food Technol. 38: 121-130.

Morrissey, P. A., D. M. Mulvihill, and E. M. O’Neill. 1987. Functional properties of muscle proteins. B.J. F. Hudson (Ed.), Developments in food proteins, Elsevier Science Pub., Co, New York, NY.

Munoz, A. M. 1986. Development and application of texture reference scales. J. Sensory Stud. I: $55-83$.

Neely, T. R., C. L. Lorenzen, R. K. Miller, T. D. Tatum, J. W. Wise, J. F. Taylor, M. J. Buyck, J. O. Reagan and J. W. Savell. 1999. Beef customer satisfaction: cooking method and degree of doneness effects on the top round steak. J. Anim. Sci. 77: 653-660. 
Offer, G. and Knight, P. 1988. The structural basis of water-holding capactity in meat. Part 1: general principles and water uptake in meat processing. In R. Lawrie (Ed.). Developments in meat science. New York: Elsevier Applied Science. 4: 61-171.

Offer, G., P. Knight, R. Jeacocke, R. Almond, T. Cousins, and J. Elsey. 1989. The structural basis of the water-holding, appearance and toughness of meat and meat-products. Food Microstructure. 8: 151-170.

Pearson, A. M. and T. A. Gillett. 1996. Processed Meats. Springer Publishing Company. New York, NY.

Peleg, M. 1987. The basics of food rheology. Food Texture, Instrumental and Sensory Measurement . Marcel Dekker. New York, NY.

Petsko, G. A., and D. Ringe. 2004. Protein structure and function. New Science Press. Corby. Northants, UK 1:4.

Phillips, L. G., D. M. Whitehead and J. E. Kinsella. 1994. Stucture- function propertied of food proteins. Food Science and Technology international series.

Pomeranz, A. 1991. Functional Properties of Food Components. Pages 155-165. Academic Press. San Diego, CA.

Puolanne, E., M. H. Ruusunen, and J. I. Vainionpaa. 2001. Combined effects of $\mathrm{NaCl}$ and raw meat $\mathrm{pH}$ on water holding in cooked sausage with and without added phosphate. Meat Sci. 58: 1-7.

Purslow, P. P. 2005. Intramusclar connective tissue and role in meat quality. Meat Sci. 70: 435447. 
Rakosky, J. 1970. Soy products for the meat industry. J. Agric. Food Chem. 18: 1005-1009.

Ruusunen, M., E. Puolanne. 2005. Reducing sodium intake from meat products. Meat Sci. 70: $531-541$.

Rose, G. D., A. R. Geselowitz, G. J. Lesser, R. H. Lee and M. H. Zehfus. 1985. Hydrophobicity of amino acid residues in globular proteins. Science. 229: 834-838.

SAS Institute, Inc. 2004. SAS User's Guide. SAS Institute Inc., Cary, NC.

Schut, J. 1976. Food Emulsions. S. Friberg, M. Dekker, Inc. New York, NY.

Siegel, D. G., K. E. Church and G.R. Schmidt. 1979. Gel structure of non-meat proteins as related to their ability to bind meat pieces. J. Food Sci. 44:1276-1279, 1294.

Smith, D. M. 1988. Meat proteins: functional properties in comminuted meat products. Food Technol. 42: 116-121.

Swaisgood, H.E. 1996. Characteristics of milk. Pages 841-878 in Food Chemistry. O. R. Fennema Ed. Marcel Dekker, New York.

Swan, J. E. and J. A. Boles. 2002. Processing characteristics of beef roasts made from normal pH inside rounds. Meat Sci. 62: 399-403.

Szcsesniak, A. S. 1963. Classification of textural characteristics. J. Food Sci. 28: 384-389.

Tornberg, E. 2005. Effects of heat on meat proteins- implications on structure and quality of meat products. Meat Sci. 70: 493-508. 
Totosaus, A., J. G. Montejano, J. A. Salazar, and I. Guerro. 2002. A review of physical and chemical protein- gel induction. J. Food Sci. Technol. 37: 598-601.

Trout, E. S., M. C. Hunt, D. E. Johnson, J. R. Claus, C. L. Kastner, and D. H. Kropf. 1992. Characteristics of low-fat ground beef containing texture-modifying ingredients. J. Food Sci. 57: 19-24

USDA. 2011. Ground Beef and Food Safety. Accessed Feb 11, 2012. http://www.fsis.usda.gov/PDF/Ground_Beef_and_Food_Safety.pdf.

USDA. 1998. USDA Proposed rules: meat produced by advanced meat/ bone separation machinery and recovery systems. Federal Register, 63: 1759-1765.

Wiley, E. L., J. O. Reagan, J. A. Carpenter, and D. R. Campion. 1979. Connective tissue profiles of various raw sausage materials. J. Food Sci. 44: 918-919.

Xiong, Y. L. 1997. Food proteins and their interactions. Pages 341-392 in Structure- Function Relationships of Muscle Proteins. Damodaran, S., Paraf, A. Eds. Marcel Dekker, New York.

Youssef, M. K. and S. Barbut. 2009. Effects of protein level and fat/oil on emulsion stability, texture, microstructure and color of meat batters. Meat Sci. 82: 228-233.

Zorba, O. 2005. The effects of the amount of emulsified oil on the emulsion stability and viscosity of myofibrillar proteins. Food Hydrocoll. 20: 698-702. 
Table 1: Formulations of meat batters prepared with different lean meat and salt levels ( $\%$ by volume)

\begin{tabular}{|c|c|c|c|c|c|}
\hline Treatment & Raw Material & $\begin{array}{l}\text { Meat * } \\
(\%)\end{array}$ & $\begin{array}{l}\text { Ice* } \\
(\%)\end{array}$ & $\begin{array}{l}\text { Whey* } \\
(\%)\end{array}$ & $\begin{array}{l}\text { Salt } \\
(\%)\end{array}$ \\
\hline $1^{3}$ & $\mathrm{FTB}^{1}$ & 88.0 & 8.0 & 4.0 & 0.0 \\
\hline $1^{3}$ & 90/10 Trim & 88.0 & 8.0 & 4.0 & 0.0 \\
\hline $1^{3}$ & Bull Chuck Trim & 88.0 & 8.0 & 4.0 & 0.0 \\
\hline $1^{3}$ & Shank Meat & 88.0 & 8.0 & 4.0 & 0.0 \\
\hline $1^{3}$ & $\mathrm{BTFT}^{2}$ & 88.0 & 8.0 & 4.0 & 0.0 \\
\hline $2^{4}$ & FTB $^{1}$ & 86.2 & 8.0 & 4.0 & 1.8 \\
\hline $2^{4}$ & 90/10 Trim & 86.2 & 8.0 & 4.0 & 1.8 \\
\hline $2^{4}$ & Bull Chuck Trim & 86.2 & 8.0 & 4.0 & 1.8 \\
\hline $2^{4}$ & Shank Meat & 86.2 & 8.0 & 4.0 & 1.8 \\
\hline $2^{4}$ & $\mathrm{BTFT}^{2}$ & 86.2 & 8.0 & 4.0 & 1.8 \\
\hline \multicolumn{6}{|c|}{$*$ All percentages were within $\pm 0.20 \%$} \\
\hline $\begin{array}{l}\text { 1: FTB - Fin } \\
\text { 2: BTFT - BC }\end{array}$ & $\begin{array}{l}\text { xtured beef } \\
\text { s trimmed finely textured }\end{array}$ & \multicolumn{4}{|c|}{$\begin{array}{l}\text { 3: Formulation containing } 0.0 \% \text { salt } \\
\text { 4: Formulation containing } 2.5 \% \text { salt }\end{array}$} \\
\hline
\end{tabular}


Table 2: Texture Profile Analysis texture parameters for raw materials at salt level: $0.0 \%$

\begin{tabular}{lccccc}
\hline Raw & & & & \\
Material & Hardness & Cohesiveness & Springiness & Gumminess & Chewiness \\
\hline FTB & $23.13^{\mathrm{c}}$ & $0.65^{\mathrm{c}}$ & $0.20^{\mathrm{a}}$ & $1520.96^{\mathrm{c}}$ & $306.83^{\mathrm{c}}$ \\
BT & $60.97^{\mathrm{b}}$ & $0.73^{\mathrm{a}}$ & $0.16^{\mathrm{b}}$ & $4515.99^{\mathrm{b}}$ & $902.12^{\mathrm{a}}$ \\
BCM & $65.92^{\mathrm{ab}}$ & $0.75^{\mathrm{a}}$ & $0.13^{\mathrm{c}}$ & $5062.74^{\mathrm{a}}$ & $1083.55^{\mathrm{a}}$ \\
SM & $74.13^{\mathrm{a}}$ & $0.74^{\mathrm{a}}$ & $0.15^{\mathrm{c}}$ & $5531.34^{\mathrm{a}}$ & $817.31^{\mathrm{b}}$ \\
BTFT & $65.53^{\mathrm{ab}}$ & $0.66^{\mathrm{b}}$ & $0.21^{\mathrm{a}}$ & $4372.47^{\mathrm{b}}$ & $896.45^{\mathrm{a}}$ \\
\hline Raw Material: FTB- finely textured beef (FTB), BT- 90/10 trim, BCM- bull chuck meat, SM- shank meat, \\
BTFT - boneless trimmed finely textured beef (BTFT).
\end{tabular}

Superscripts a,b,c,d,e denote significant difference between raw materials within row 
Table 3: Texture Profile Analysis texture parameters for raw materials at salt level: $1.80 \%$

\begin{tabular}{lccccc}
\hline Raw & & & & \\
Material & Hardness & Cohesiveness & Springiness & Gumminess & Chewiness \\
\hline FTB & $27.80^{\mathrm{d}}$ & $0.68^{\mathrm{b}}$ & $0.20^{\mathrm{a}}$ & $1899.55^{\mathrm{d}}$ & $375.72^{\mathrm{c}}$ \\
BT & $83.41^{\mathrm{b}}$ & $0.67^{\mathrm{b}}$ & $0.20^{\mathrm{a}}$ & $5656.35^{\mathrm{b}}$ & $1101.98^{\mathrm{a}}$ \\
BCM & $93.66^{\mathrm{a}}$ & $0.72^{\mathrm{a}}$ & $0.17^{\mathrm{b}}$ & $6784.12^{\mathrm{a}}$ & $1120.85^{\mathrm{a}}$ \\
SM & $94.80^{\mathrm{a}}$ & $0.73^{\mathrm{a}}$ & $0.16^{\mathrm{b}}$ & $6990.81^{\mathrm{a}}$ & $1109.56^{\mathrm{a}}$ \\
BTFT & $55.16^{\mathrm{c}}$ & $0.60^{\mathrm{c}}$ & $0.21^{\mathrm{a}}$ & $3347.22^{\mathrm{c}}$ & $685.00^{\mathrm{b}}$ \\
\hline \multicolumn{4}{l}{ Raw Material: FTB- finely textured beef (FTB), BT- 90/10 trim, BCM- bull chuck meat, SM- shank meat, } \\
BTFT - boneless trimmed finely textured beef (BTFT).
\end{tabular}

Superscripts a,b,c,d,e denote significant difference between raw materials within row 
Table 4: Texture Profile Analysis texture parameters: combined salt levels

\begin{tabular}{lccccc} 
Raw & & & & & \\
Material & Hardness & Cohesiveness & Springiness & Gumminess & Chewiness \\
\hline FTB & $25.46^{\mathrm{e}}$ & $0.67^{\mathrm{d}}$ & $0.20^{\mathrm{b}}$ & $1710.25^{\mathrm{e}}$ & $341.28^{\mathrm{e}}$ \\
BT & $72.19^{\mathrm{c}}$ & $0.70^{\mathrm{c}}$ & $0.18^{\mathrm{c}}$ & $5086.17^{\mathrm{c}}$ & $1002.20^{\mathrm{b}}$ \\
BCM & $79.79^{\mathrm{b}}$ & $0.74^{\mathrm{a}}$ & $0.15^{\mathrm{e}}$ & $5923.43^{\mathrm{b}}$ & $1102.20^{\mathrm{a}}$ \\
SM & $84.47^{\mathrm{a}}$ & $0.73^{\mathrm{b}}$ & $0.16^{\mathrm{d}}$ & $6261.07^{\mathrm{a}}$ & $963.43^{\mathrm{c}}$ \\
BTFT & $60.34^{\mathrm{d}}$ & $0.63^{\mathrm{e}}$ & $0.21^{\mathrm{a}}$ & $3859.84^{\mathrm{d}}$ & $790.72^{\mathrm{d}}$ \\
\hline
\end{tabular}

Raw Material: FTB- finely textured beef (FTB), BT- 90/10 trim, BCM- bull chuck meat, SM- shank meat, BTFT - boneless trimmed finely textured beef (BTFT).

Superscripts a,b,c,d,e denote significant difference between raw materials within row 
Table 5: Texture Profile Analysis texture parameters at salt level $0.00 \%$ and $1.80 \%$ : combined raw materials

\begin{tabular}{lccccc} 
Salt & Hardness & Cohesiveness & Springiness & Gumminess & Chewiness \\
\hline 1 & $57.94^{\mathrm{b}}$ & $0.71^{\mathrm{a}}$ & $0.17^{\mathrm{b}}$ & $4200.70^{\mathrm{b}}$ & $801.25^{\mathrm{b}}$ \\
2 & $70.96^{\mathrm{b}}$ & $0.68^{\mathrm{b}}$ & $0.19^{\mathrm{a}}$ & $4935.61^{\mathrm{a}}$ & $878.62^{\mathrm{a}}$ \\
\hline
\end{tabular}

Salt level: 1- $0.00 \%$ salt, $2-1.80 \%$ salt

Superscripts $a, b$ denote significant difference between raw materials within row 
Table 6: Cook loss for all raw materials

\begin{tabular}{lccc}
\hline Raw Material & $0.00 \%$ Salt & $1.80 \%$ Salt & Combined Salt Level \\
\hline FTB & $30.27^{\mathrm{a}}$ & $21.14^{\mathrm{a}}$ & $25.71^{\mathrm{a}}$ \\
BT & $26.62^{\mathrm{b}}$ & $13.90^{\mathrm{c}}$ & $20.24^{\mathrm{e}}$ \\
BCM & $28.02^{\mathrm{a}}$ & $15.90^{\mathrm{b}}$ & $22.41^{\mathrm{c}}$ \\
SM & $27.91^{\mathrm{a}}$ & $16.91^{\mathrm{b}}$ & $21.94^{\mathrm{d}}$ \\
BTFT & $29.66^{\mathrm{a}}$ & $20.91^{\mathrm{a}}$ & $25.28^{\mathrm{b}}$ \\
\hline
\end{tabular}

Raw Material: FTB- finely textured beef (FTB), BT- 90/10 trim, BCM- bull chuck meat, SM- shank meat, BTFT boneless trimmed finely textured beef (BTFT).

Superscripts a,b,c,d,e denote significant difference between raw materials within row 
Table 7: Chemical analysis of raw materials at salt level: $0.0 \%$

Raw

Materia

FTB

$\mathrm{pH}$

Fat (\%) $\quad$ Moisture (\%)

Protein $(\%)$

BT

$5.64^{\mathrm{a}} \quad 3.20$

$70.48^{\mathrm{b}}$

$17.38^{\mathrm{b}}$

BCM

$5.91^{\circ}$

9.16

$76.48^{d}$

$18.91^{\mathrm{c}}$

SM

$5.98^{\mathrm{c}}$

$2.03^{\mathrm{a}}$

$75.58^{c}$

$20.27^{\mathrm{d}}$

BTFT

$6.12^{\mathrm{d}}$

$2.07^{\mathrm{b}}$

$58.91^{\mathrm{a}}$

$20.88^{\mathrm{e}}$

Raw Material: FTB- finely textured beef (FTB), BT- 90/10 trim, BCM- bull chuck meat, SM- shank meat, BTFT - boneless trimmed finely textured beef (BTFT).

Superscripts a,b,c,d,e denote significant difference between raw materials within row 
Table 8: Chemical analysis of raw materials at salt level: $1.8 \%$

\begin{tabular}{lcccc}
\hline Raw & & & \\
Material & $\mathrm{pH}$ & Fat $(\%)$ & Moisture $(\%)$ & Protein $(\%)$ \\
\hline FTB & $6.05^{\mathrm{a}}$ & $3.77^{\mathrm{b}}$ & $77.52^{\mathrm{e}}$ & $16.07^{\mathrm{b}}$ \\
BT & $6.11^{\mathrm{e}}$ & $7.37^{\mathrm{d}}$ & $68.70^{\mathrm{b}}$ & $18.23^{\mathrm{c}}$ \\
BCM & $6.06^{\mathrm{b}}$ & $1.69^{\mathrm{a}}$ & $75.17^{\mathrm{d}}$ & $20.13^{\mathrm{d}}$ \\
SM & $6.11^{\mathrm{c}}$ & $5.09^{\mathrm{c}}$ & $72.22^{\mathrm{c}}$ & $20.17^{\mathrm{e}}$ \\
BTFT & $6.11^{\mathrm{d}}$ & $21.96^{\mathrm{e}}$ & $57.65^{\mathrm{a}}$ & $16.27^{\mathrm{a}}$ \\
\hline Raw Material: FTB- finely textured beef (FTB), BT- $90 / 10$ trim, BCM- bull chuck \\
meat, SM- shank meat, BTFT - boneless trimmed finely textured beef (BTFT) \\
\multicolumn{5}{l}{} \\
\multicolumn{5}{l}{}
\end{tabular}


Table 9: Chemical analysis of raw materials: combined salt level

\begin{tabular}{lcccc} 
Raw Material & $\mathrm{pH}$ & Fat $(\%)$ & Moisture $(\%)$ & Protein $(\%)$ \\
\hline FTB & $5.58^{\mathrm{a}}$ & $3.49^{\mathrm{b}}$ & $77.80^{\mathrm{e}}$ & $16.72^{\mathrm{b}}$ \\
BT & $6.01^{\mathrm{b}}$ & $8.27^{\mathrm{d}}$ & $69.59^{\mathrm{b}}$ & $18.57^{\mathrm{c}}$ \\
BCM & $6.02^{\mathrm{c}}$ & $1.86^{\mathrm{a}}$ & $75.83^{\mathrm{d}}$ & $20.20^{\mathrm{d}}$ \\
SM & $6.12^{\mathrm{d}}$ & $21.70^{\mathrm{e}}$ & $58.28^{\mathrm{a}}$ & $16.48^{\mathrm{a}}$ \\
BTFT & $6.13^{\mathrm{e}}$ & $3.58^{\mathrm{c}}$ & $73.90^{\mathrm{c}}$ & $20.52^{\mathrm{e}}$ \\
\hline
\end{tabular}

Raw Material: FTB- finely textured beef (FTB), BT- 90/10 trim,

BCM- bull chuck meat, SM- shank meat, BTFT - boneless

trimmed finely textured beef (BTFT)

Superscripts a,b,c,d,e denotes significant difference between raw materials 